\title{
THE USE OF THE ERP-CRM-CIM SYSTEMS WITHIN THE MASTER'S DEGREE PROGRAMMES
}

\author{
Virgil Chichernea, Phd,vchichernea@rau.ro \\ Romanian-American University, Bucharest
}

\begin{abstract}
This paper proposes a conceptual framework for the development, integration and evaluation of ERP-CRM-CIM (Enterprise Requirements Planning - Customer Relationship Management - Computer Integrated Manufacturing) Systems into teaching education program. One of the problems in using ERP-CRM-CIM systems has been the complexity of large-scale systems and there for the main topics of this paper are: basic components, evolution ERP-CRM-CIS systems, benefits, costs, replacing/ reimplementing, family issues, structuring the manufacturing Database, successful of these systems, etc. In addition to this paper reports the development, evaluation and use of ERP-CRM-CIM systems and software packages in the Romanian-American University as well as plans for continous development and integration into the curriculum.
\end{abstract}

\section{Introduction}

Starting with the Academic Year 2002-2003, the Romanian American University, Bucharest, has received the approval from the Ministry of Education and Research to organize Master's Degree Programmes, as well. There are curently 9 ongoing master's Degree programmes organized by majors and coordinated by the respective Departments in the University. The Master's Degree in "Economic Informatics" started in the academic year 2003-2004, is coordinated by Management Information Systems Department and is organized in three semesters according to the following curriculum approved of by the Ministery of Education and Research:

\section{$1^{\text {St }}$ Semester:}

Database Management and Data Processing Techniques;

Software Quality Management;

Strategic Management;

E-business and Aplplied Software;

$2^{\text {nd }}$ Semester:

Design, Creating and Developing Client/Server Applications (I);

Decission Support Systems;

Web Application Design and Arhitecture(I);

Methodologies for the Creation/Implementation Projects within Small and Medium Size Companies;

$3^{\text {rd }}$ Semester:

Design, Creating and Developing Client/Server Applications (II);

Web Application Design and Arhitecture(II);

Complex Information Systems Management;

Information System Legislation and Security;

Finalizing the Dissertation Paper 
A workshop has also been organized every year in March (we have reached the $5^{\text {th }}$ edition), within this programme, and the resulting papers presented have been published in a book edited in English. Within the Curriculum of several Master's Degree programmes, students have as the object of study ERP-CRM-CIM Systems, the main goal of which is shaping economic information systems, bearing in mind future users and specialists in the economic field.

2. Overview of an ERP System . The basic architecture for an ERP system consists of 12 business functions utilizing a common manufacturing database, as shown in the following figure.

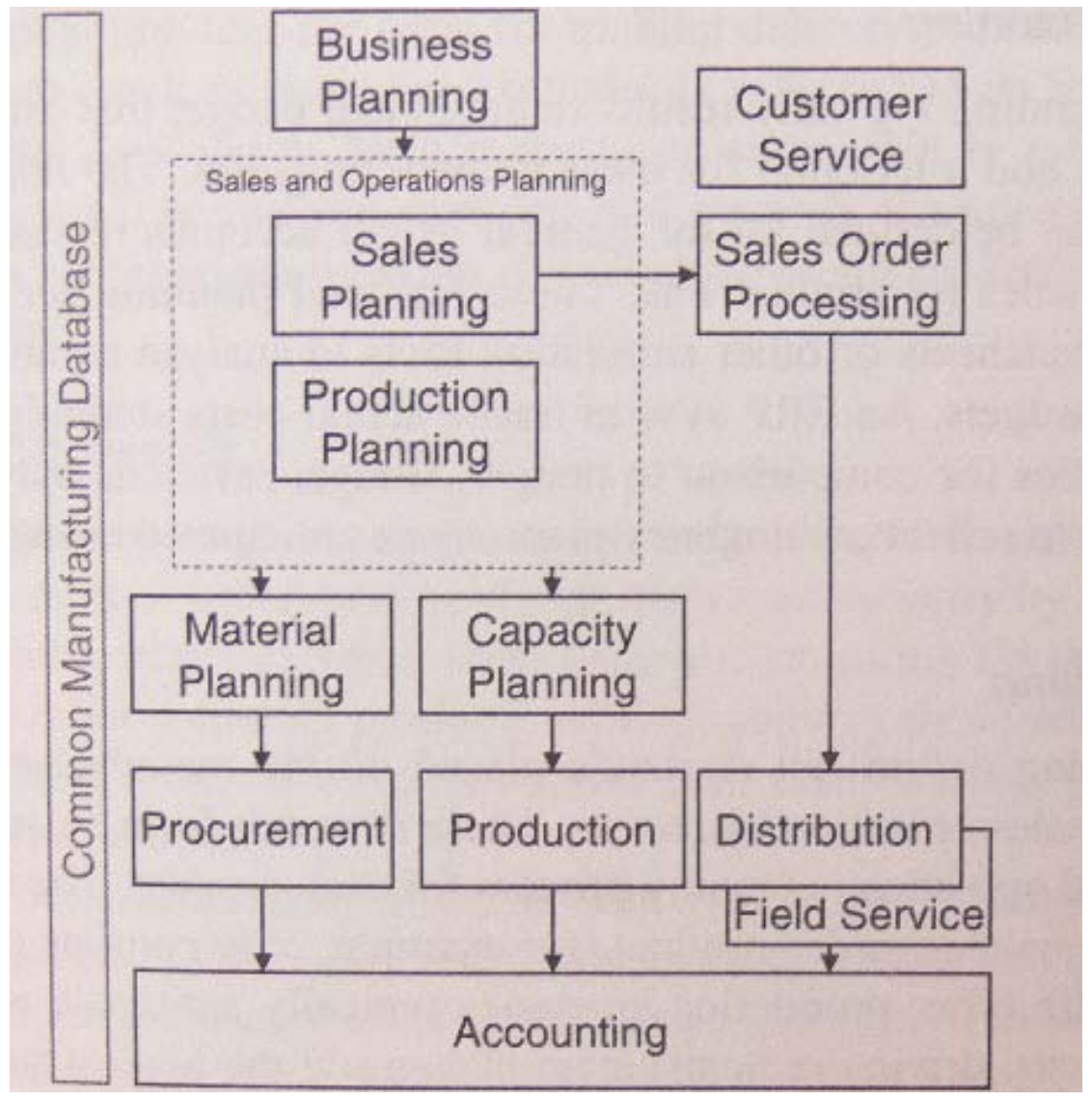

This top-down model shows how aggregate plans (the business, sales, and production plans) drive the detailed ones for coordinating supply chain activities. The accounting function tracks the financial implications of supply chain activities. The common database master files and the 12 functions are presented briefly :Common Manufacturing Database - contains the following files:customers, vendors, products, inventory locations, and general ledger accounts;

- Business Planning;

- Sales Planning;

- Production Planning;

- Material Planning

- Procurement

- Production

- Distribution

- Field Service
- Accounting

- Sales Order Processing

- Customer Service

- Capacity Planning 


\section{The connection between ERP, CRM, e-Business and Business Intelligence}

CRM systems and e-business interact with ERP components to achieve the wanted functions. In this respect, one can give examples like:

1. B2C or B2B appeal ERP components to process the applications;

2. Data processed by ERP are archived in data warehouses and they are processed using OLAP tools. The results of the analyses are used by BI components to take decisions and draft business plans.

3. The connection between ERP, CRM and e-business.

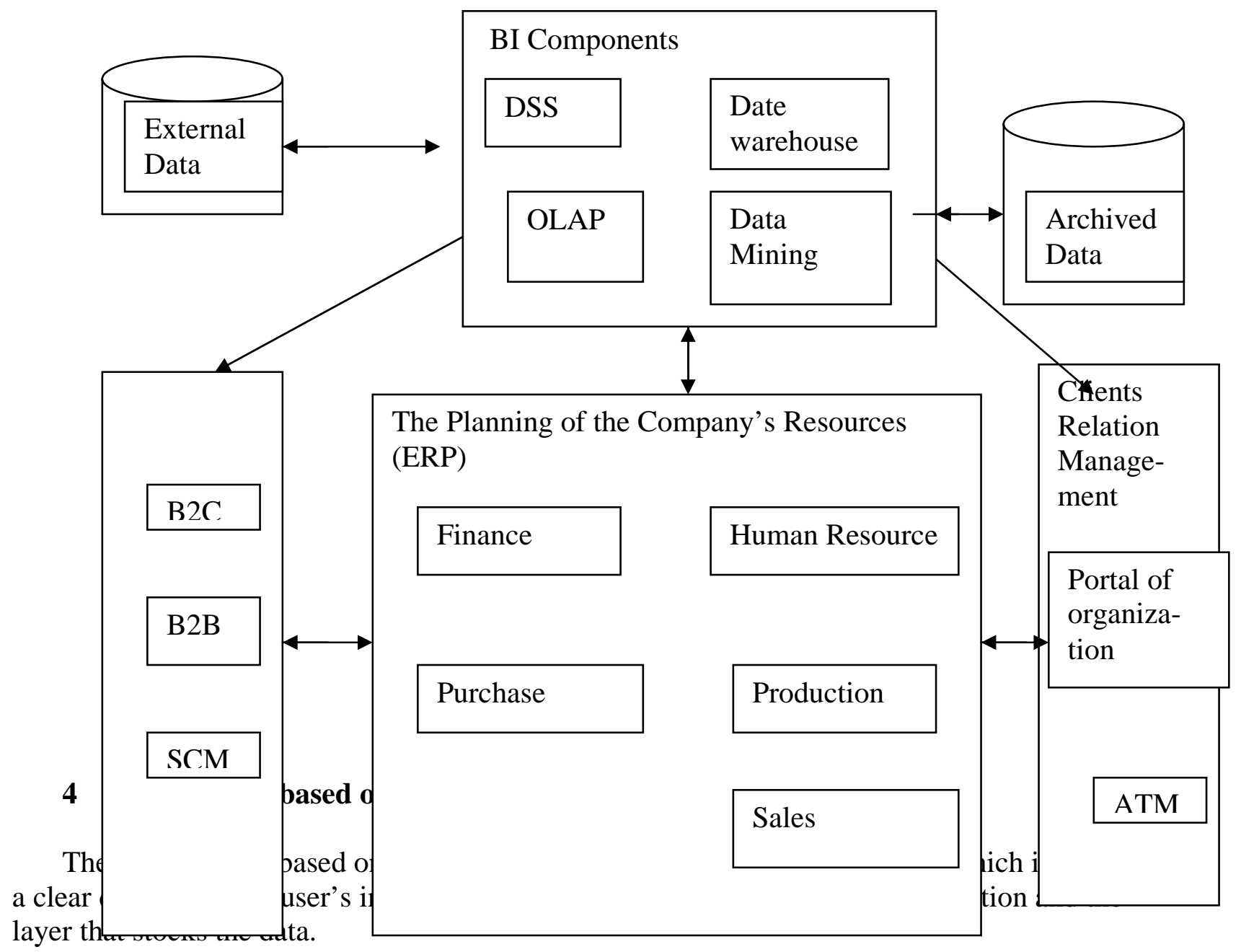

Layers:

- User interface layer $-\rightarrow$ supports all the functions related to the user interfaces;

- Business layer - this are include:

$>$ Process components - implements functions specific to the process

meant to develop the application.

$>$ Business domain components - implements common functions from many processes from a certain domain. 
Technical infrastructure layer - these components offer technical services from the economic components.

From the architecture of an application to benefit from the reusable advantages, it should contain the following layers:

\begin{tabular}{|c|c|c|c|c|}
\hline \multirow[b]{2}{*}{$\begin{array}{l}\text { Basic economic } \\
\text { process }\end{array}$} & \multicolumn{4}{|c|}{ Function specific to the applications } \\
\hline & Stocks Ad. & $\begin{array}{l}\text { Order } \\
\text { Adm. }\end{array}$ & $\begin{array}{l}\text { Accounts } \\
\& \text { Payments }\end{array}$ & .... \\
\hline \multirow{3}{*}{$\begin{array}{l}\text { Classes and } \\
\text { reusable } \\
\text { components }\end{array}$} & \multicolumn{4}{|c|}{ Common functions for many domains } \\
\hline & \multicolumn{4}{|c|}{ Technical services for the economic components } \\
\hline & \multicolumn{4}{|c|}{ Technologies that depend on platform (Java/J2EE, .NET, etc) } \\
\hline
\end{tabular}

\section{Microsoft approach regarding the IT systems architecture in a company}

Company architecture concept represents a map of the company and a planning of the business and technological changes and it is made up of a dozen models that describe the structure and its functions.

EA structure is made up of: objectives and purpose/place; the processes that take in a company; the existing systems and data; the used technology.

Microsoft uses four general "views" in order to define EA:

- business perspective;

- application perspective;

- information perspective;

- technology perspective.

\begin{tabular}{|l|l|l|l|l|}
\hline & $\begin{array}{l}\text { Conceptual } \\
\text { view }\end{array}$ & Logic view & Physical view & $\begin{array}{l}\text { Implementation } \\
\text { view }\end{array}$ \\
\hline $\begin{array}{l}\text { Business } \\
\text { perspective }\end{array}$ & $\begin{array}{l}\text { Actors and } \\
\text { business usage } \\
\text { cases (Type of } \\
\text { business) }\end{array}$ & & & \\
\hline $\begin{array}{l}\text { Application } \\
\text { perspective }\end{array}$ & $\begin{array}{l}\text { Actors and use } \\
\text { cases (the } \\
\text { model of } \\
\text { requirements) }\end{array}$ & $\begin{array}{l}\text { The analysis model and } \\
\text { system projection } \\
\text { model }\end{array}$ & $\begin{array}{l}\text { Detailed } \\
\text { projection } \\
\text { model .. }\end{array}$ & $\begin{array}{l}\text { Diagram of } \\
\text { components. } \\
\text { Diagram of } \\
\text { development }\end{array}$ \\
\hline $\begin{array}{l}\text { Information } \\
\text { perspective }\end{array}$ & $\begin{array}{l}\text { The model of } \\
\text { the area's } \\
\text { objects. }\end{array}$ & $\begin{array}{l}\text { Entities class. } \\
\text { Activities diagrams }\end{array}$ & Data model & \\
\hline
\end{tabular}




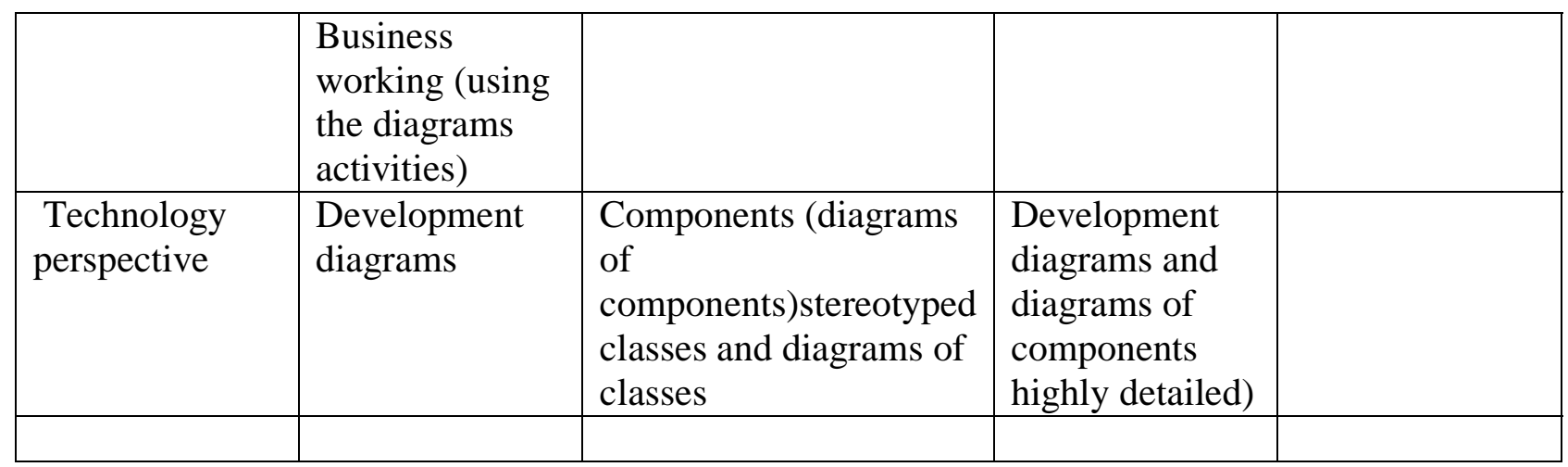

6. Microsoft business solutions - NAVISION

NAVISION - is an integrated solution for the management of small and medium sized enterprises and displays IT applications for: management, production, distribution, relations management, service management, e-commerce and analysis.

\section{THE PRODUCT'S COMPONENTS:}

\section{SECTION 1 FINANCIAL MANAGEMENT}

\begin{tabular}{ll} 
Module: BASIC ACCOUNTING & Module: DEBTS \\
\hline Module: Liquidity Admin. & Module : CLAIMS \\
\hline Module: FIXED ASSETS & SECTION 2: ANALYSES SECTION 3: \\
\hline LOGISTICS & Module: WAREHOUSE MANAG. \\
\hline Module: STOCKS ADMIN. & Moction 4: PRODUCTION \\
\hline Module: PRODUCTION BASIS & Module: PLANNING OF PRODUCTION \\
\hline Module: PURCHASING PLANNING. & CAPACITIES \\
SECTION 5: CLIENT RELATION MANAGEMENT & Module: SERVICE MANAGEM. \\
\hline Module: SALES \& MARKETING & SECTION 8: BASIC POINT \\
\hline SECTION 6: HUMAN RESOURCE MANAGEMENT & SECTION 10: DEVELOPMENT \\
SECTION 7: RESOURCE PLAN & INSTRUMENTS/TOOLS
\end{tabular}

SECTION 11: ADDITIONAL FUNCTIONS

\section{Implementation recommendations}

ERP systems benefits justify the investments made by the economic units. Yet many enterprises don't achieve the potential benefits of the ERP systems because their implementation and use is inefficient. The suggestions to increase the use of these systems depend on the concise conditions of the enterprise, especially small and medium -sized enterprises and the capabilities of the system end refer mainly to:

- Data bases structure regarding the manufacture;

- Sales and operational plans; 
- Sales management;

- Purchasing activities management;

- Accounting and report of results.

In order to increase the use of ERP systems it is recommended to begin with the Financial Section, the applications invoicing, cost control, accounting and financial then it should be added many functions from Financial, Relation Management Production, Distribution, e- Business, Analyses.

\section{Bibliography:}

1. Scott Hamilton - Maximizing your ERP System. A practical Guide for Managers. McGraw Hill - New York, Chicago... 2003;

2.Microsoft Business Solution - NAVISION 4.0

3. Microsoft CRM 3.0 - www.microsoft.com/crm

4. Novensys for Management (Novensys for Warehouse /Novensys for Assets)

5. www.novensys.com

6. www.microsoft.com/BusinessSolution 